\title{
ФОСИЛИЗОВАНЕ ГРЕШКЕ У ПИСАНОЈ ПРОДУКЦИЈИ УЧЕНИКА ИТАЛИЈАНСКОГ ЈЕЗИКА (НИВО Б2)
}

АПСТРАКТ: Фосилизација као феномен који се неминовно јавља у међујезику ученика током процеса учења циљног језика већ дуго је предмет студија у области учења другог или страног језика. Упркос томе што контрастивне студије на пољу италијанског језика ${ }^{1}$ нису изостале, истраживања спроведена у неколико последњих деценија била су више теоријског него емпиријског карактера. Стога је циљ овог рада био да кроз анализу грешака корпуса изнесе резултате емпиријског истраживања у намери да идентификује најчешће фосилизоване грешке ученика са нивоом знања Б2 ${ }^{2}$ италијанског језика, како би се број грешака током процеса учења редуковао, а настава језика побољшала креирањем дидактичког материјала намењеног посебно србофоним ученицима италијанског. Информанти су били двадесет четири ученика приватне школе страних језика у Београду чија је писана продукција анализирана после завршеног нивоа А2, а потом и после завршетка нивоа Б2, а онда њихове грешке упоређене. Резултати су показали да, упркос обуци од две године, изложености циљном језику, исправкама, додатним вежбањима и објашњењима у међујезику ученика перзистирају извесне грешке, иако се веровало да ће на овом нивоу знања (Б2 $)^{3}$ бити искорењене.

Кључне речи: фосилизација, грешке, анализа грешака, међујезик, италијански језик, србофони говорници, ниво А2, ниво Б2.

\footnotetext{
${ }^{1}$ Видети: Terić 1996; Moderc 2005; Ceković 2007; Radojević 2014; Janićijević 2016.

2 Ниво се одређује према Заједничком европском оквиру за живе језике: https://www.coe.int/en/web/common-european-framework-reference-languages/leveldescriptions.

${ }^{3}$ Премда се по дефиницији (Selinker 1972) фосилизоване грешке сматрају онима које постоје у међујезику ученика на нивоу када се очекује да оне буду искорењене упркос изложености језику, вежбању, објашњењима професора или било којој другој врсти интервенције, при чему се не помиње прецизан временски период који је потребан да би се грешка сматрала фосилизованом, желели смо да ученицима дамо довољно времена (ниво Б1) да грешке типичне за ниво А2 искорене, па смо одлучили да истраживање спроведемо после нивоа Б2.
} 


\title{
FOSSILIZED ERRORS IN THE WRITTEN PRODUCTION OF ITALIAN LANGUAGE STUDENTS (B2 LEVEL)
}

\begin{abstract}
Fossilization, a phenomenon that inevitably occurs in the interlanguage of students learning the target language, has been the subject of studies in the field of second language acquisition for a long time. Nevertheless, the research studies carried out in the past few decades have been more theoretical than empirical. Therefore, the purpose of this paper is to present the results of empirical research in an attempt to identify the most common fossilized errors of students at the B2 level in the Italian language in order to reduce the number of errors during the learning process and to improve language teaching by creating didactic materials specially designed for Serbophone students of Italian. The participants were 24 students in a private language school in Belgrade whose written production was analyzed after the completion of the A2 level and then after the completion of the B2 level, and their errors were compared. The results showed that, in spite of two years of exposure to the target language, certain errors persist in the learner's interlanguage although it was believed that at the B2 level they would disappear.
\end{abstract}

Key words: fossilization, errors, error analysis, interlanguage, Italian language, Serbophone speakers, level A2, level B2.

\section{1. ТЕОРИЈСКИ ОКВИР ИСТРАЖИВАФА}

Фосилизација ${ }^{4}$ као феномен који се неминовно јавља у међујезику ученика који уче циљни језик већ дуго је предмет студија у области учења другог или страног језика. Наставници језика непрекидно се суочавају са појавом да одрасли ученици нису у могућности да достигну ниво компетенције у циљном језику једнак оном који имају у матерњем језику (Lenneberg 1967; Selinker 1972; Han 2004). Узрок оваквој врсти стагнације, када ученикови међујезици престану да се развијају, јесте фосилизација.

Како би се разумео феномен фосилизације, који је у фокусу нашег интересовања, неопходно је да се претходно појасни појам међујезика.

Термин „међујезик” (енгл. Interlanguage) први пут је формално употребио Селинкер 1969. године (Selinker 1972: 214) да опише нематерњи језички систем који ученик другог или страног језика ствара у свакој од фаза учења кроз које пролази, почевши од лингвистичког инпута којем је изложен, а који је независан од језика који ученик учи, као и од матерњег језика ученика. Аутор је на тај начин пружио теоријски оквир за тумачење учења другог језика као менталног процеса.

4 Видети: Selinker 1972, 1992; Adjemian 1976; Tarone 1979, 1994; Ellis 1982, 1985, 1992; Han 2004; Saville-Troike 2006. 
Крајем шездесетих и почетком седамдесетих година прошлог века, Селинкер је био само један од аутора који се бавио овим феноменом. Кордер (Corder 1967) је предложио термин „транзиторна компетенција” (енгл. transitional competence), а неколико година касније (Corder 1971) и термин „идиосинкратични дијалекат” (енгл. idiosyncratic dialect). Немсер (Nemser 1971) говори о „,апроксимативном систему” (енгл. approximative system), док he се касније појавити и много мање познати термини као: ,језички системи ученика" (енгл. learner language systems, Richards \& Sampson 1973), „посреднички систем” (франц. système intermédiaire, Porquier 1974), „приближни систем” (франц. système approché, Noyau 1976) и „транзиторијална конструкција” (engl. transitorial construction, Dulay et al. 1982) (према Ellis 1985: 47; Fernandez 1997: 19; Sánchez Iglesias 2003: 42).

Наведени аутори описали су међујезик на различите начине, али, поред специфичности које дефиниција међујезика може имати за сваког од поменутих лингвиста, постоје основне идеје у којима се аутори слажу: 1) ради се о језичком систему који је структурисан, 2) овај систем се развија и пролази кроз различите фазе током процеса учења, 3) независан је и од матерњег и од циљног језика, 4) састављен је од матерњег језика, циљног језика, али и других језика који су ученици претходно учили, 5) учење другог језика помера се у правцу циљног језика, при чему ученик сукцесивно гради системе фонолошких, граматичких и семантичких правила, 6) захваљујући међујезику могу се објаснити ментални процеси кроз које ученик пролази током учења страног језика.

Лингвисти који су се бавили проучавањем међујезика (Selinker 1972, 1992; Adjemian 1976; Tarone 1979, 1994; Ellis 1982, 1985, 1992; Han 2004; Saville-Troike 2006) верују да међујезик карактеришу: систематичност, пермеабилност (пропустљивост), стабилност, динамичност, варијабилност, регресија и фосилизација.

\footnotetext{
„Фосилизовани лингвистички феномени су језички елементи, правила и подсистеми које ће говорници одређеног матерњег језика тежити да задрже у својим међујезицима у односу на одређени циљни језик, без обзира на узраст ученика или количину објашњења или инструкције које добија на циљном језику" (Selinker 1972: 215)
}

5 Fossilizable linguistic phenomena are linguistic items, rules, and subsystems which speakers of a particular native language will tend to keep in their interlanguage relative to a particular target language, no matter what the age of the learner or amount of explanation or instruction he receives in the target language (Selinker 1972: 215). 
На овај начин Селинкер, покушавајући да одговори на питање зашто већина ученика не успева да достигне језичку компетенцију изворних говорника, објашњава један од најзначајнијих принципа који се тичу међујезика - фосилизацију. Фосилизација је феномен који значи да нематерњи говорник у својим међујезицима има тенденцију да задржава одређене карактеристике матерњег језика (лингвистичке елементе, правила и подсистеме) без обзира на узраст, ниво образовања или комуникацијске потребе. Може се дефинисати као стање када се међујезик ученика више не развија у правцу циљног језика, без обзира на то колико је ученик изложен циљном језику, као и упркос исправкама, објашњењима или било којој другој врсти интервенције. Појава фосилизованих елемената није случајна, већ природна и очекивана. Фосилизоване структуре обично се јављају у језичким продукцијама ученика не само када се веровало да су искорењене, већ и када је говорникова пажња усредсређена на нову интелектуалну потешкоћу или се он налази у стању узнемирености или узбуђења, или чак када је потпуно опуштен (Selinker 1972: 215, Selinker 1972: 221).

Фосилизација може постојати у свим језичким подсистемима. Говорници различитих матерњих језика ће имати тенденцију да имају различите, карактеристичне фосилизоване структуре у својим међујезицима које не могу нестати из њихових међујезика, без обзира на количину инпута који добијају када су се структура или подсистем већ фосилизовали.

Иако су студије на тему фосилизације спроведене у последњих неколико деценија биле више теоријске а мање емпиријске, нема сумње да је фосилизација један од најзначајнијих елемената који се тичу међујезика и учења другог/страног језика уопште. Лингвисте који су проучавали наведени феномен (Vigil \& Oller 1976; Brown 1980; Ellis 1985; Skehan 1998; Mitchell \& Myles 1998; Lightbown \& Spada 1999; Han 2004) занимало је следеће:

1. зашто у одређеним контекстима постоје структуре учениковог матерњег језика које се одражавају на језику који учи и које не може да избегне, чак и онда када је научио све карактеристике циљног језика;

2. зашто се фосилизација јавља чак и на високим нивоима учења страног језика;

3. зашто ученици на различите начине пролазе кроз фосилизацију;

4. због чега ученици показују другачије резултате и под готово истим условима учења страног језика и

5. зашто и како долази до заустављања у процесу учења. 
Наведени аутори закључили су да на ова питања није лако одговорити јер није увек лако одредити шта је фосилизација с обзиром на то да ову појаву може изазвати више узорака.

\section{2. ИНФОРМАНТИ И МЕТОД}

Циљ емпиријског истраживања које смо спровели био је да кроз анализу грешака корпуса састављеног од есеја, диктата и завршних испита ученика идентификује и класификује најчешће фосилизоване грешке ученика са нивоом знања Б2 италијанског језика ${ }^{6}$ како би се резултати истраживања применили у настави и олакшао пут србофоним говорницима који уче италијански језик.

Током овог лонгитудиналног истраживања коришћена је метода анализе грешака. Информанти су били двадесет четири ученика (19 жена и 5 мушкараца) приватне школе страних језика у Београду. Узраст испитаника био је између 18 и 32 године. На курс су се уписали као апсолутни почетници, без претходног познавања италијанског језика. Сви полазници курсева били су нелингвисти. Говорили су енглески језик (ниво Б1 или Б2 према самопроцени), а током школовања учили су још један страни језик (немачки, руски или француски) у коме нису имали високу компетенцију (ниво А1 или А2 према самопроцени). Мотиви за похађање курса италијанског језиика били су следећи: 1. посао (16 полазника), 2. студирање наставак школовања у Италији (4 полазника), 3. хоби (4 полазника). Дакле, двадесет (20) полазника имало је тзв. инструменталну мотивацију за учење језика ${ }^{7}$.

6 Уџбеник који је коришћен током курса био је Nuovo progetto italiano издавачке куће Edilingua. Једанаест лекција које је подразумевао ниво А2 обухватале су следеће области: правила читања и писања, једнину и множину именица и придева, личне заменице, помоћне глаголи essere и avere, одређени и неодређени члан, презент индикатива правилних, неправилних и модалних глагола, предлоге, предлоге здружене са чланом, присвојне придеве и заменице, перфекат (Passato prossimo) правилних и неправилних глагола, футур 1 (Futuro semplice) и футур 2 (Futuro anteriore) правилних и неправилних глагола, имперфекат (Imperfetto) и плусквамперфекат (Trapassato prossimo) правилних и неправилних глагола, дативне и акузативне заменице са партитивном заменицом пе, повратне глаголе, императив, садашњи и прошли кондиционал правилних и неправилних глагола.

7 Постоје две основне врсте мотивација за учење језика (Gardner 1985; Brown 2000): интегративна и инструментална. Прва се односи на жељу ученика да комуницирају или се интегришу са говорницима циљног језика. Сматра се да ученици који воле 
Ученици су похађали курсеве италијанског језика два пута недељно, са укупним фондом од 128 часова за два семестра, односно једну годину учења за ниво А2 и 256 часова за четири семестра, односно две године учења за ниво Б2. Наставу су похађали искључиво у школи, нико од полазника није похађао додатну наставу, нити језик учио у иностранству.

Обављено је квантитативно истраживање, а као мерни инструмент узети су диктати, есеји и завршни испити двадесет четири полазника курса италијанског језика. Корпус чине 264 диктата ученика анализираних после завршеног А2 нивоа и 264 диктата анализираних после завршеног Б2 нивоа. Поред диктата, корпус чине и есеји (264 састава од 50 до 80 речи за ниво А2, односно 264 састава од 120 до 140 речи за ниво Б2). Теме есеја односиле су се описивања физичког изгледа и карактера особе, породице, годишњег одомора, путовања, описивања куће, школе, празника, климе, екологије, здравог живота, музике, књига, куповине, моде и друштвених мрежа. Трећи део корпуса чинило је 48 завршних испита који су се састојали од искључиво граматичких вежбања. Анализиране су правописне, лексичке и морфосинтаксичке грешке три групе од по 8 ученика по завршеном нивоу А2, а затим упоређене са грешкама које су исти ученици направили на нивоу Б2 италијанског језика. Циљ је био да се установи које грешке су и даље присутне у међујезику ученика и после две године учења италијанског језика. Како је већ напоменуто, одлучили смо да тестирамо ученике тек после нивоа Б2, и свесно прескочили ниво Б1, како бисмо ученицима дали довољно времена (ниво Б1) да савладају пређено градиво и искорене грешке типичне за ниво А2.

\section{3. РЕЗУЛТАТИ ИСТРАЖИВАҢА}

Грешке које смо уочили приликом анализе корпуса класификовали смо у три групе: правописне, лексичке и морфосинтаксичке.

изворне говорнике језика, диве се култури и имају жељу да се интегришу у друштво у којем се језик користи као матерњи обично лакше и брже науче језик од ученика који немају сличне афинитете. Другу врсту мотивације карактеришу практични разлози за учење језика: полагање испита, проналажење бољег посла или већа зарада због знања језика, читање техничког материјала или постизање вишег социјалног статуса. 


\section{1. Правописне грешке}

У правописне грешке сврстали смо оне грешке које су настале услед непоштовања правописних правила италијанског језика. Најучесталије правописне грешке које су ученици на нивоу А2 правили јесу следеће:

3.1.1. удвојени консонанти у оквиру једне речи (итал. doppie) проблем се манифестовао на два начина: ученици су или изостављали један од два консонанта (*ogi уместо oggi, *ocupato уместо occupato, *viagio уместо viaggio, *ghiacio уместо ghiaccio, *spechio уместо specchio, *capuccino или *cappucino уместо cappuccino, *chiachierare уместо chiacchierare, *azzuro уместо azzurro, *capello уместо cappello, *scimia уместо scimmia, *pastasciuta уместо pastasciutta) или су вршили хиперкорекцију, односно писали удвојене консонанте у речима у којима се они не пишу у италијанском језику (*etta уместо età, *baccio уместо bacio, *vocce уместо voce, *maggico уместо magico, *orologgio уместо orologio, *reggina уместо regina, *stassera уместо stasera, *neccessario уместо necessario, *ogetto или peђе *oggeto уместо oggetto);

3.1.2. акценат - као и у претходном случају, грешка се испољавала на два начина: ученици су изостављали акценте на последњем вокалу (* eta уместо età, *virtu уместо virtù, *curiosita уместо curiosità, *gioventu уместо gioventù, *parlera уместо parlerà, *preparero уместо preparerò), или, ређе, бележили графички акценат онда када у италијанским речима он не постоји (*mатта̀ уместо татта).

И код удвојених консонаната и код акцента узрок прве врсте проблема вероватно потиче из матерњег језика ученика у ком се у оквиру једне речи не бележе ни удвојени консонанти, ни акценти. Друга врста проблема је интралингвалне природе и представља хиперкорекцију. Ученици знају за постојање удвојених консонаната и акцентованих речи у циљном језику, па правила (погрешно) примењују и у случајевима када то није потребно, како би се што више приближили норми стандардног италијанског језика;

3.1.3. изостављање италијанског слова „H” - консонант „H” се у италијанском језику никад не изговара, служи да „гради диграме $\mathrm{CH}$ i $G H$ којима се означавају веларни гласови $/ \mathrm{K} /$ и $/ \mathrm{G} /$ испред вокала $E$ и $I$ " (Dardano $\&$ Trifone 1995: 687). Наведене грешке указују не само на недовољно познавање ортографских правила (*mascera уместо maschera, *giaccio уместо ghiaccio, *pageremo уместо pagheremo, *cercerò уместо cercherò, *sciena уместо schiena, *sceletro уместо scheletro, *ungia уместо unghia, *scerzo уместо scherzo), већ и граматичких правила која се тичу грађења множине 
именица и придева (*lunge уместо lunghe, *giacce уместо giacche, *sporci уместо sporchi, * gnocci уместо gnocchi);

3.1.4. апостроф - ученици нису бележили апостроф у следећим случајевима императива: * $v a$ уместо $v a$ ', *di уместо $d i$ ', *fa уместо $f a$ ' и код *cè уместо c'è, *ce ne ипо уместо се n'è uno.

Као и у претходном случају, није реч искључиво о правописним грешкама, већ истовремено и о граматичким грешкама које могу довести до конфузије услед непознавања морфолошких и семантичких разлика. Наиме, облици va и fa јесу 3. лице једнине презента глагола andare и fare, док је облик $d i$ предлог.

Графикон бр. 1: Најзаступљеније правописне грешке после завршеног нивоа А2

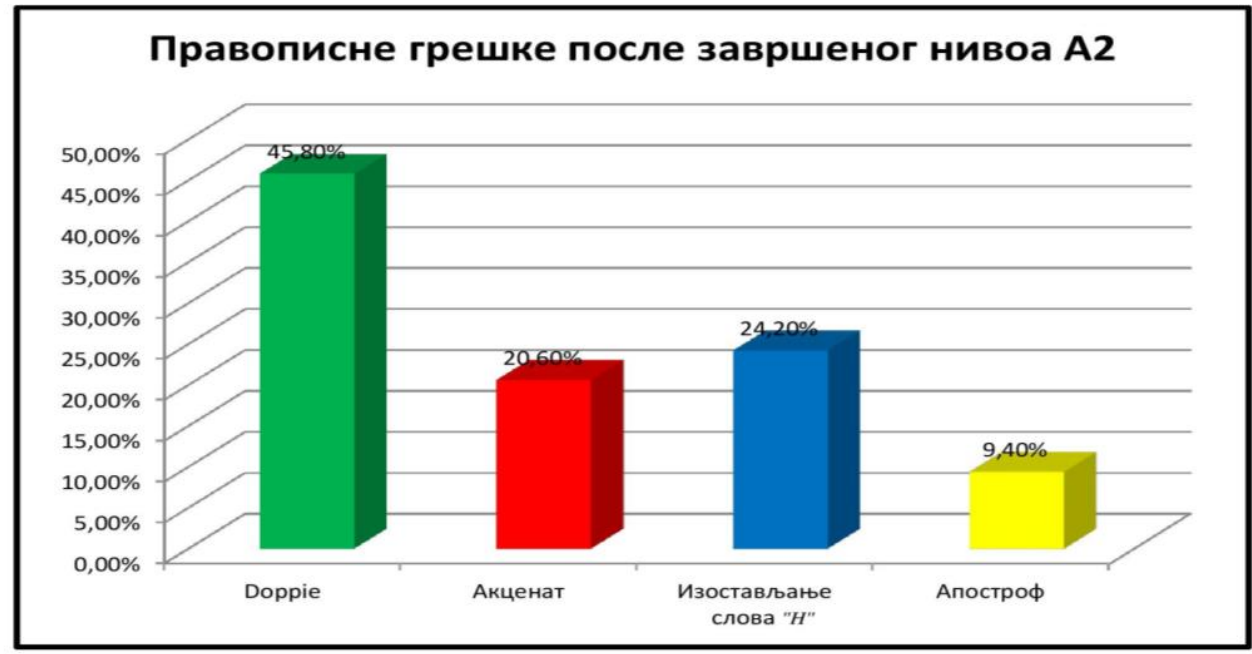

После анализе грешака корпуса прикупљеног после нивоа Б2 уочено је да од напред наведених грешака доминирају оне које се тичу удвојених консонаната. Ученици су писали: *acettare или *accetare уместо accettare, *comerciante уместо commerciante, *fazoletto или *fazzoleto уместо fazzoletto, *petegolezzo или *pettegolezo уместо pettegolezzo, *canelloni или *canneloni уместо cannelloni, *cocodrillo или *coccodrilo уместо coccodrillo, *sciochezza или *scioccheza уместо sciocchezza, *profesoressa или *professoresa уместо professoressa, *capuccino или *cappucino уместо cappuccino, *passegiata уместо passeggiata, *accetterebero или *acceterebbero уместо accetterebbero, *Apennini или *Appenini или *Apenini уместо Appennini, *afettare или *affetare уместо affettare. 
Сви испитивани полазници имали су проблем са писањем удвојених консонаната на диктатима рађеним на часу. Примећено је да на овом нивоу ученици најчешће изостављају дупле консонанте у речима у којима се два или три пута појављују doppie.

Када су у питању остале грешке, ученици су потпуно савладали правило о писању консонанта „H”, док су се ретко појављивале грешке везане за употребу акцента (*sofa уместо sofà, *gioventu уместо gioventù, *maturita уместо maturità, *liberta уместо libertà, *mercoledi уместо mercoledi) или апострофа (*ce пѐ уместо се n'è, *un ро уместо ип ро').

Графикон бр. 2: Правописне грешке после завршеног нивоа Б2

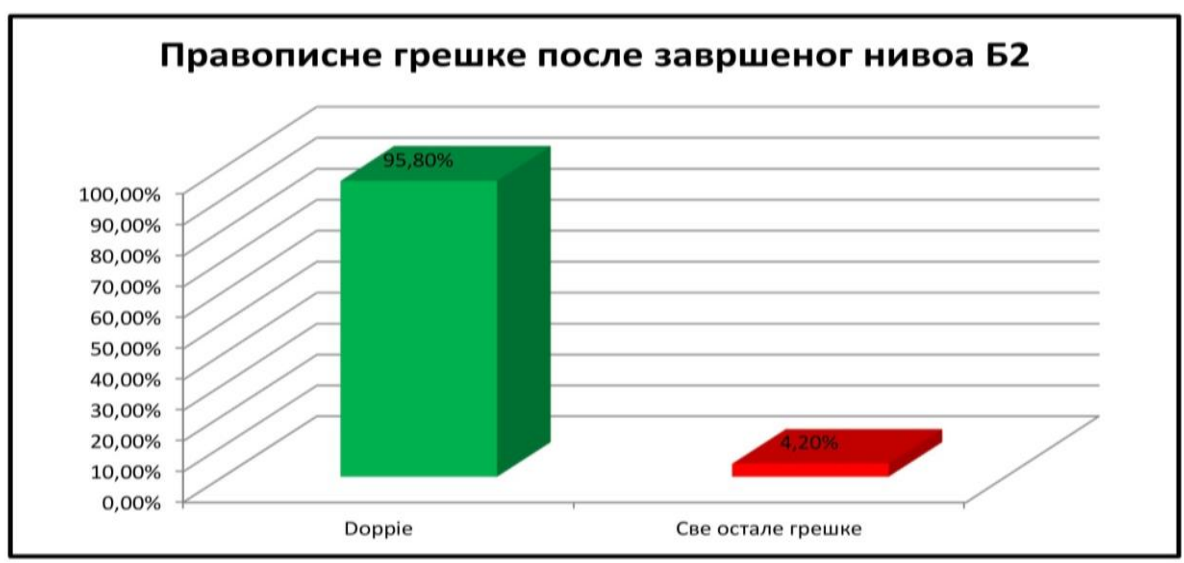

\section{2. Лексичке грешке}

Уопштено говорећи, под лексичким грешкама подразумевамо све оне грешке које су настале због погрешно употребљене лексике, односно речника италијанског језика. Нивои А1 и А2 обухватају речнички фонд између 1.800 и 2.000 речи. Полазници курсева били су у могућности да додатно обогате свој лексички фонд на часовима конверзације. Лексика коју је требало да усвоје на прва два нивоа учења италијанског тицала се описивања физичког изгледа и карактера особе, породице, описивања куће, школе, хобија, путовања, празника, хране, уметности, биоскопа, музике, куповине, продавница и одеће. На часовима су додатно могли да науче речи које се тичу климе, екологије, здравог живота, књига и друштвених мрежа.

На нивоу А2 лексичке грешке су се огледале у коришћењу појединих речи из матерњег или неког другог раније наученог језика, најчешће енглеског. Наиме, услед недостатка компетенције и непознавања 
одговарајуће италијанске речи, ученици су, како би ипак пренели жељену поруку, користили трансфер као стратегију и преносили речи из претходно научених језика које су познавали. У том смислу трансфер се огледао најчешће кроз потпуне позајмљенице (енгл. she уместо итал. lei, енгл. I уместо итал. io, енгл. coffee уместо итал. caffè, срп. da уместо итал. che), хибридне творевине (*lusire - коришћење енгл.основе loose и итал. наставка ire) и лажне пријатеље (*parenti (рођаци) у значењу „родитељи”, према енгл. parents уместо итал. genitori; *caldo (топло) у значењу „хладно” према енгл. cold уместо итал. freddo; *carta (папир) у значењу „карта”, према срп. карта уместо итал. biglietto; *camera (соба) у значењу „камера”, према срп. камера уместо итал. cinepresa; *regalo (поклон) у значењу „регал”, према срп. регал уместо итал. armadio; *piazza (трг) у значењу „пијаца”, према срп. пијаца уместо итал. mercato; *stipendio (плата) у значењу „стипендија”, према срп. стипендија уместо итал. borsa di studio). На нивоу Б2 потпуно су ишчезле грешке које се тичу потпуних позајмљеница и хибридних творевина, а спорадично су се јављали лажни пријатељи ( уређај”, према срп. клима уместо итал. climatizzatore; *firma (потпис) у значењу „фирма”, према срп. фирма уместо итал. ditta; *locazione (изнајмљивање) у значењу „локација”, према срп. локација уместо итал. ubicazione; *patente (дозвола) у значењу „патент”, према срп. патент уместо итал. brevetto; *cornetto (кроасан, кифла) у значењу „корнет”, према срп. корнет уместо итал. сопо).

Вредна помена је грешка коју су ученици често правили и на нивоу А2 и на нивоу Б2. Услед утицаја матерњег језика, ученици су погрешно користили италијански глагол andare (који се користи да означи удаљавање од говорника или саговорника) уместо глагола venire (којим се изражава приближавање говорнику или саговорнику):

- Andiamo al cinema. *Vai con noi? (демо у биоскоп. Да ли идеш са нама?) уместо исправног облика: Andiamo al cinema. Vieni con noi? (Идемо у биоскоп. Да ли долазиш са нама?)

Из наведених примера закључује се да су најчешће грешке биле интралингвалног карактера, док је интерлингвалних грешака било занемарљиво мало.

Будући да лексичке грешке не представљају тип грешака које су се фосилизовале код наших ученика, али и због економичности излагања навели 
смо само неколико најупечатљивијих примера грешака. После нивоа А2 оне су чиниле око 6\%, а на нивоу Б2 нешто више од 2\% укупног броја грешака.

\section{3. Морфосинтаксичке грешке}

Под морфосинтаксичким грешкама подразумевамо оне грешке које су настале услед неправилног грађења речи или граматички неисправних реченица због непоштовања или погрешне примене граматичких правила италијанског језика. Ради се о некој врсти девијације у односу на норму која постоји у стандардном италијанском језику, а тичу се готово свих категорија речи. Након извршене анализе грешака у писаној продукцији ученика, после завршеног нивоа А2, као најучесталије издвојиле су се следеће грешке:

\subsection{1. Чланови - ученици су правили четири типа грешака:}

a) изостављали су његову употребу: *Ragazza che ho incontrato si chiama Jovana уместо La ragazza che ho incontrato si chiama Jovana, *Mio amico Petar vive a Cesena уместо Il mio amico Petar vive a Cesena, *Sono nato 20 ottobre уместо Sono nato il 20 ottobre, tutte persone* уместо tutte le persone.

Будући да матерњи језик ученика не препознаје категорију члана, ученици су настојали да ту особеност пренесу и у циљни језик. Наиме, дословно су преводили реченице са српског на италијански језик, те им у италијанским реченицима није недостајао члан јер га није било ни у њиховом матерњем језику;

б) употребљавали су члан када то није било потребно: *Conosco la sua sorella da due anni уместо Conosco sua sorella da due anni, *Mio padre è il medico уместо Mio padre è medico, *nella questa città уместо in questa città, *una settimana della vacanza уместо una settimana di vacanza, *nella piazza San Giovanni уместо in piazza San Giovanni, *vado nell'albergo уместо vado in albergo.

Свесни да једну од најчешћих интервенција професора током часа представља подсећање на коришћење члана у италијанском језику, ученици су правили неку врсту хиперкорекције - тежили су да примене правило о коришћењу члана у случајевима када то није било потребно;

в) користили су погрешан облик члана: *Il straniero уместо lo straniero, *il anno уместо l'anno, *la insegnante уместо l'insegnante, *dei amici уместо degli amici, *i Stati Uniti уместо gli Stati Uniti.

Осим употребе члана, ученици су наилазили на потешкоће и када је у питању облик члана. Наиме, у италијанском језику при избору одговарајућег члана треба водити рачуна не само о роду и броју, већ и о речи уз коју члан 
стоји. Дакле, због чињенице да је приликом употребе члана било потребно узети у обзир више параметара, ученици су правили грешке због комплексности задатка;

г) употребљавали су одређени члан уместо неодређеног: *Firenze è la bella città уместо Firenze è una bella città, *È il problema difficile уместо Ѐ un problema difficile, *è il ragazzo italiano уместо è un ragazzo italiano.

Ова врста грешке не потиче из матерњег језика, већ је реч о недовољно добро савладаном правилу циљног језика. Као и код претходне групе грешака, ради се о томе да категорију члана србофони ученици тешко савладавају јер је немају у свом матерњем језику.

После анализе грешака радова ученика на нивоу Б2 установљено је да од набројаних грешака перзистирају грешке у употреби члана LO (*il specchio уместо lo specchio, *il zaino уместо lo zaino, *il studioso уместо lo studioso, *il psicologo уместо lo psicologo, *il stress уместо lo stress, *il stipendio уместо lo stipendio, *il sciopero уместо lo sciopero, *il scandalo уместо lo scandalo).

3.3.2. Предлози - са овом категоријом речи србофони ученици имају највише проблема на свим нивоима учења италијанског језика (в. Radojević 2014). Додатни проблем представља употреба предлога са чланом. Најчешће грешке које се тичу предлога на нивоу А2 јесу:

a) предлог A: *a città уместо in città, *parto a Roma уместо parto per Roma, *prima alle 8 уместо prima delle 8 , *ho portato la macchina al meccanico уместо ho portato la macchina dal meccanico, *l'Arena a Verona уместо l'Arena di Verona, *il treno alle sette уместо il treno delle sette.

Ученици су на једном од првих часова италијанског језика научили да се испред имена градова користи предлог „А” у значењу српског предлога „У” (Vivo a Belgrado - Живим у Београду). Услед лажне аналогије користили су предлог „А” испред имена градова и у свим осталим контекстима (после глагола partire који захтева употребу предлога per, или уместо италијанског предлога „DI” којим се означава припадање Università di Belgrado Београдски универзитет). Слично томе, ученицима је било познато да се за исказивање времена/сати најчешће користи предлог спојен са чланом „ALLE” (Pranzo alle due - Ручам у два сата), па су, поново условљени лажном аналогијом, користили овај предлог са чланом и у осталим случајевима (уместо предлога DI у примеру: il treno alle sette уместо il treno delle sette где се предлог „DI” користи у својој темпоралној спецификативној функцији (Radojević, 2014: 69) и у примеру *prima alle 8 уместо prima delle 8 , односно после речи „PRIMA” која изискује употребу предлога „DI”). Дакле, овде је 
реч о интралингвалним грешкама које су настале услед хиперкорекције одређених правила италијанског језика;

б) предлог IN: *mia sorella vive in Vienna уместо mia sorella vive a Vienna, *Ci vediamo in lunedì уместо $\mathrm{Ci}$ vediamo lunedì, *è ancora in letto уместо ѐ ancora a letto, *salgo in tram уместо salgo sul tram, *si è innamorata in Vittorio уместо si è innamorata di Vittorio.

У готово свим наведеним примерима очигледан је негативни трансфер из матерњег језика ученика, односно буквални превод српског предлога „У” италијанским предлогом „IN” (Живим у Бечу, Видимо се у понедељак, још увек је у кревету, заљубила се у Виторија);

в) предлог DI: *Vado di mia madre уместо Vado da mia madre, *non dipende di mе уместо non dipende da me, *Vengo di Belgrado уместо Vengo da Belgrado, *lontano della fermata уместо lontano dalla fermata, *preferisco la discoteca del teatro уместо preferisco la discoteca al teatro, *Oggi torna del Portogallo уместо Oggi torna dal Portogallo, *davanti di noi уместо davanti a noi, *sono riuscito di уместо sono riuscito a;

г) предлог DA: *Ho studiato la lingua francese da 8 anni уместо Но studiato la lingua francese per 8 anni.

Наведени пример представља једну од најучесталијих грешака. Наиме, уместо италијанског предлога „PER”, који се користи као темпорални акузатив за изражавање временског трајања предикације (в. Radojević 2014: 148), ученици су користили предлог „DA” којим се означава „само почетак несвршене предикације, тј. предикације која траје и у тренутку говорења" (Radojević 2014: 153);

д) предлог SU: *vado sul mare уместо vado al mare, *ha aperto il libro sulla pagina sbagliata уместо ha aperto il libro alla pagina sbagliata, *mi sono arrabbiato su mia sorella уместо mi sono arrabbiato con mia sorella, *vado sul concerto уместо vado al concerto.

Као и у случају предлога „IN”, наведене грешке су настале као последица интерференције, тачније буквалног превода са матерњег језика (идем 쓰 море, отворио сам књигу на погрешној страни, наљутио сам се 쓰 моју сестру, идем на концерт) и погрешног уверења ученика да he се у свим случајевима српски превод НА превести италијанским предлогом „SU”;

ђ) предлог PER: *Studio italiano per quattro mesi уместо Studio italiano da quattro mesi, *Il treno parte per cinque minuti уместо Il treno parte tra/fra cinque minuti, *vado per dormire уместо vado a dormire, *occhiali per sole уместо occhiali da sole. 
И у случају предлога „PER” уочљив је негативни трансфер из српског

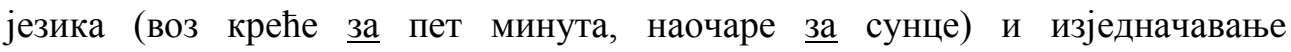
италијанског предлога „PER” и српског предлога „ЗА”;

е) предлог CON: *contento con уместо contento di, *ci siamo sentiti con telefono уместо сі siamo sentiti per/al telefono, *si occupa con politica уместо si occupa di politica.

Еквивалент италијанског предлога „CON” био би српски предлог „CA” којим се изражава инструментална функција. Наведено објашњава примере грешака условљене дословним преводом са матерњег језика ученика (задовољан чиме, чули смо се телефоном, бави се политиком);

ж) предлог TRA/FRA: *fra la finestra del mio soggiorno уместо dalla finestra del mio soggiorno.

После завршеног нивоа Б2 као фосилизоване су остале следеће грешке: *mi fido in te уместо mi fido di te, *nel menù уместо sul menù, *nei giornali уместо sui giornali, *ho preso le valigie della macchina уместо ho preso le valigie dalla macchina, *gli studenti stanno seduti sui loro banchi уместо gli studenti stanno seduti nei loro banchi, * ritorno per due settimane уместо ritorno tra/fra due settimane, *cercavo per le mie carte уместо cercavo fra/tra le mie carte, *faccio la spesa nel fruttivendolo уместо faccio la spesa dal fruttivendolo, *nella periferia della città уместо alla periferia della città, *arrivava a casa alle sette e le otto уместо arrivava a casa tra le sette e le otto, *scendi sulla quarta fermata уместо scendi alla quarta fermata.

У оба случаја (после завршених нивоа А2 и Б2) код употребе предлога уочен је јак утицај негативног трансфера из матерњег језика, што побројане грешке чини грешкама интралингвалне природе. Грешке су, код највећег броја ученика, настале дословним преводом са српског језика (*mi fido in te - имам поверења У тебе, *nei giornali - У новинама, *ritorno per due settimane - враћам се ЗА две недеље, *scendi sulla quarta fermata - сиђи НА четвртој станици), иако се наведена употреба предлога обрађивала на А1 и А2 нивоу. Проблем везан за усвајање ове категорије речи није својствен само србофоним ученицима. Доказ је и чињеница да су аутори ажурираног издања уџбеника Nuovo progetto italiano осмислили додатна вежбања која се тичу употребе предлога после сваке лекције, без обзира на граматичку партију која се у тој лекцији обрађује. 


\subsection{3. Именице}

Грешке везане за употребу именица класификовали смо у три групе:

a) род именица: *la cinema уместо il cinema, *la problema уместо il problema, *il mano уместо la mano, *la sistema уместо il sistema, *il televisione уместо la televisione.

Иако су досадашњи примери указивали на чињеницу да су грешке ученика углавном настајале услед негативног међујезичког утицаја из матерњег у страни језик, грешке везане за род именица су интралингвалне природе, односно настале су услед недовољно савладаних правила (и изузетака) италијанског језика, тј. њихове хипергенерализације;

б) род именица на -E: *il legge уместо la legge, *il voce уместо la voce, *la pesce уместо il pesce, *il chiave уместо la chiave, *il frase уместо la frase, *il classe уместо la classe, *la paese уместо il paese.

У италијанском језику именице које се завршавају вокалом $-E$ могу бити и мушког и женског рода, тј. ученици према облику именице не могу закључити ког је рода именица (као што је случај са именицама које се завршавају на вокал $-O$ или $-A$ ). Услед недовољне компетенције на страном језику, ученици су приписивали (погрешан) род италијанској именици, руководећи се родом коју та именица има у српском језику (*il legge - закон м.p., *il voce - глас м.р., *la pesce - риба ж.p., *il chiave - кључ м.p., *il classe - разред м.р., *la paese - земља ж.р.);

в) именице неправилне у множини: $*_{i}$ cinemi уместо $i$ cinema, $*_{i}$ profugi уместо $i$ profughi, *i biologhi уместо $i$ biologi, *le farmace уместо le farmacie, *le camice уместо le camicie, *le pronuncie уместо le pronunce.

Све набројане грешке јесу интралингвалне природе, односно тичу се недовољно добро савладаних правила (и изузетака) циљног језика.

После завршеног нивоа Б2 искорењене су све врсте наведених грешака.

\subsection{4. Придеви}

Резултати истраживања показују да употреба придева не ствара превелике потешкоће ученицима ни на једном нивоу. После завршеног нивоа А2 уочили смо следеће грешке:

а) придеви QUALCHE и QUANTO: *qualche amiche уместо qualche amica, *qualche anni уместо qualche anno, *quanto anni hai? уместо quanti anni hai? 
Грешка везана за придев QUALCHE јесте интралингвална јер ученици нису усвојили правило да се после овог придева увек користи именица у једнини. С друге стране, грешка која се тиче придева QUANTO је интерлингвална. Наиме, ученици су правило о непроменљивости српског придева КОЛИКО пренели и у циљни језик, где се овај придев слаже у роду и броју са именицом испред које стоји;

б) придеви QUELLO, BELLO и BUONO: *quel amico уместо quell' amico, *quel studente уместо quello studente, *buon studio! уместо buono studio!, *quello tиo zio уместо quel tuo zio, *bello ragazzo уместо bel ragazzo.

Ради се о интралингвалној грешци јер ученици наведена три придева нису скраћивали у случајевима када то налаже норма италијанског језика;

в) положај придева: *una verde camicia уместо una camicia verde, *un importante lavoro уместо un lavoro importante, *un sorridente ragazzo уместо un ragazzo sorridente.

Неисправан положај придева у италијанском језику јасно указује на негативни трансфер из српског језика, где је положај придева испред, а не иза именице као што је најчешће случај у италијанском језику.

После завршеног нивоа Б2 ишчезле су грешке везане за придеве QUALCHE и QUANTO, и положај придева, али је и даље остала присутна погрешна употреба придева QUELLO, BELLO и BUONO. Грешке илуструјемо следећим примерима: *quelli stivali уместо quegli stivali, *quelli pantaloni уместо quei pantaloni, *quel esame уместо quell'esame, *belli amici уместо begli amici, *quelli signori уместо quei signori, *quelli studenti уместо quegli studenti, *un bel albero di Natale уместо un bell' albero di Natale.

\subsection{5. Заменице}

Најучесталије грешке које се тичу заменица, после завршеног нивоа А2 курса италијанског представљају:

a) показне заменице - *questo è mia sorella уместо questa è mia sorella, *questo sono i nostri genitori уместо questi sono i nostri genitori.

У наведеним примерима поново је евидентан утицај матерњег језика ученика где се показна заменица ОВО не слаже у роду и броју са именицом на коју се односи (ово је моја сестра, ово су наши родитељи);

б) заменица NE: Quanti ragazzi hai invitato? *Ho invitato 10 уместо Ne ho invitati 10, Quante riviste leggi alla settimana? *Leggo due уместо Ne leggo due. 
Заменица NE представља непостојећу категорију у српском језику. Будући да је нема у њиховом матерњем језику, ученици су је доживљавали као сувишни елемент, те је нису користили ни у италијанском где је употреба ове заменице неопходна;

в) слагање заменица са партиципом: Quanti ragazzi hai invitato? *Ne ho invitato tanti уместо Ne ho invitati tanti, *Non li ho visto уместо Non li ho visti, *le ragazze le ha accompagnato Paolo уместо le ragazze le ha accompagnate Paolo, *la camicia, l'ho stirato io уместо la camicia, l'ho stirata io, *di libri ne ho letto tanti уместо di libri ne ho letti tanti;

г) повратне заменице: *dobbiamo svegliarsi уместо dobbiamo svegliarci, *dovreste alzarsi presto уместо dovreste alzarvi presto, *non potevate ricordarsi del suo numero di telefono? уместо non potevate ricordarvi del suo numero di telefono?

Навикнути на јединствени облик повратне заменице СЕ у свим лицима у српском језику, ученици су користили облик заменице $S I$ и у 1 . и 2. лицу множине уместо исправних облика $C I$ и $V I$;

д) употреба дативних уместо акузативних заменица и обрнуто: *l'ho chiesto уместо gli ho chiesto, *Le voglio aiutare уместо La voglio aiutare, *gli ho ringraziato уместо l'ho ringraziato, *L'ha sparato al petto уместо Gli ha sparato al petto.

Као и у већини досадашњих случајева, чест узрок грешака била је интерференција матерњег језика (питао сам 므, желим да Вам помогнем, захвалио сам му се, упуцао га је у груди).

После завршеног нивоа Б2 остале су неискорењене грешке које се тичу слагања заменица са партиципом и употреба заменице NE: *non ho ricevuto la tua mail, quando l'hai spedito? уместо non ho ricevuto la tua mail, quando l'hai spedita?, *ho scritto due lettere ma non le ho spedito уместо ho scritto due lettere ma non le ho spedite, *ho chiuso le porte ma il vento le ha aperto уместо ho chiuso le porte ma il vento le ha aperte, *i libri di Ammaniti li ho letti tre уместо i libri di Ammaniti ne ho letti tre, *la torta ne abbiamo mangiata quasi tutta уместо la torta l' abbiamo mangiata quasi tutta.

\subsection{6. Глаголи}

Грешке везане за глаголе односе се на грађење и употребу глаголских времена.

a) употреба времена Futuro Anteriore (футур 2): *Se sarai venuto in Italia, potrai apprezzare le bellezze artistiche del nostro Paese уместо Se verrai in 
Italia, potrai apprezzare le bellezze artistiche del nostro Paese, *Se avrò finito il lavoro presto, verrò da te уместо Se finirò il lavoro presto, verrò da te, *Dopo che finirò questo lavoro, prenderò una settimana di vacanza уместо Dopo che avrò finito questo lavoro, prenderò una settimana di vacanza.

Облици и употреба овог будућег времена обрађују се на нивоу A1 курса италијанског језика. У прва два наведена примера, грешка је настала услед утицаја матерњег језика, односно буквалног превода са српског (Ако будеш дошао у Италију..., Ако будем завршио посао ускоро...), тј. коришћења српског футура II у кондиционалним реченицама, што је у италијанском језику погрешно. Трећи пример, међутим, показује интралингвалну грешку, насталу као последица несавладаног правила италијанског језика;

б) избор помоћног глагола приликом грађења времена Passato Prossimo: *sono passeggiato уместо ho passeggiato, *ho riuscito уместо sono riuscito, *sono viaggiato уместо ho viaggiato, *Il tempo ha cambiato уместо Il tempo è cambiato, *Non ha suonato la sveglia уместо Non è suonata la sveglia, *L'estate ha finito уместо L'estate è finita, *Dante ha vissuto nel Due-Trecento уместо Dante è vissuto nel Due-Trecento, *sono camminato уместо ho camminato, *sono sceso le scale уместо ho sceso le scale, *lo sciopero ha durato уместо lo sciopero è durato, *mi ho lavato уместо mi sono lavato.

Када је у питању избор помоћног глагола, грешке су настале не као последица трансфера из српског, већ услед непотпуно савладаних правила италијанског језика. Ученици су усвојили правило да се уз глаголе кретања као помоћни користи глагол ESSERE, али нису научили изузетке од правила (*sono passeggiato, *sono viaggiato, *sono camminato). Такође, нису водили рачуна о томе да се поједини глаголи (cominciare, iniziare, finire, volare, cambiare, crescere, suonare, vivere, salire, scendere итд.) могу користити уз оба помоћна глагола, али у различитим контекстима (*Il tempo ha cambiato, *Non ha suonato la sveglia, *L'estate ha finito, *Dante ha vissuto nel Due-Trecento, *sono sceso le scale);

в) употреба времена Passato Prossimo и Imperfetto: *Ieri dormivo 10 ore уместо Ieri ho dormito 10 ore, *aspettavo l'autobus per un'ora уместо ho aspettato l'autobus per un'ora, *Prima noi andavamo in Francia, poi attraversavamo il canale della Manica e infine abbiamo raggiunto l'Irlanda уместо Prima noi siamo andati in Francia, poi abbiamo attraversato il canale della Manica e infine abbiamo raggiunto l'Irlanda, *Il mio orologio era accanto al letto e vedevo che erano le sette уместо Il mio orologio era accanto al letto e ho visto che erano le sette, *Domenica sono andato al mare perchè ha fatto molto 
caldo уместо Domenica sono andato al mare perchè faceva molto caldo, *Ieri mattina è stata domenica ed io mi sono svegliato molto tardi уместо Ieri mattina era domenica ed io mi sono svegliato molto tardi.

Узрок појаве овакве врсте грешака треба тражити превасходно у чињеници да се у српском језику аспектуалност, тј. глаголски вид изражава на лексичком плану, путем наставака за деривацију (читати - прочитати) који указују на то да ли је радња свршена или несвршена. Са друге стране, у италијанском језику глаголски вид се изражава на морфосинтаксичком плану, употребом одговарајућих прошлих времена: импефекта (Imperfetto) којим ће се означавати несвршена радња и перфекта (Passato prossimo) који означава свршену радњу;

г) употреба времена Trapassato Prossimo (плусквамперфекат): *Mia sorella ha ritrovato l'anello che ha perso alcune settimane prima уместо Mia sorella ha ritrovato l'anello che aveva perso alcune settimane prima, *Stamattina ho ricevuto il pacco che mia zia mi ha mandato per il mio onomastico уместо Stamattina ho ricevuto il pacco che mia zia mi aveva mandato per il mio onomastico, *Ho restituito ad Antonio tutte le lettere che mi ha scritto уместо Ho restituito ad Antonio tutte le lettere che mi aveva scritto, *Avevo molto sonno anche se ho dormito dieci ore уместо Avevo molto sonno anche se avevo dormito dieci ore.

Плусквамперфекат се учи на нивоу А2, па су ученици имали мање времена да савладају употребу овог времена него што је то био случај са временом Futuro Anteriore (футур 2). Будући да се иста врста грешке јавила и после нивоа Б2, верујемо на њен узрок ипак треба тражити у чињеници да се српски плусквамперфекат не користи често, већ се у овом језику претходност радње исказује помоћу прилога или придева који указују на антериорност радње (Šipčić 2013: 8). Стога су ученици, у жељи да избегну да текст звучи архаично или услед дословног превода са матерњег језика користили италијански перфекат уместо плусквамперфекта, навикнути да у матерњем језику перфекат изражава и прошлу радњу и претходност у односу на прошлу радњу;

д) употреба кондиционала уместо времена Imperfetto: *Si sarebbe alzato presto ogni mattina e si sarebbe recato all'ufficio уместо Si alzava presto ogni mattina e si recava all'ufficio (Устајао би рано сваког јутра и кретао би на посао), *Ogni estate sarei andata in campagna уместо Ogni estate andavo in campagna (Сваког лета бих одлазила на село).

Овде се ради о интерлингвалним грешкама, односно наведени примери су очигледан доказ постојања јаког трансфера из матерњег језика 
ученика. Верујемо да је реч о грешци типичној за србофоне говорнике, и да ученици чији матерњи језик није српски не би направили ову грешку, будући да је грешка настала дословним превођењем српског језика.

После анализе грешака корпуса након постигнутог нивоа Б2 закључујемо да је као фосилизована остала грешка која се тиче употребе времена: Passato Prossimo и Imperfetto и употреба времена Trapassato Prossimo, и да је проценат грешака везан за употребу прошлих времена изузетно висок $(67,4 \%)$. Навешћемо неколико примера: *Ero stanco e avevo molto sonno e perciò mi preparavo un caffè e facevo colazione уместо Ero stanco e avevo molto sonno e perciò mi sono preparato un caffè e ho fatto colazione, *Lavoravo tutta l'estate yмecmo ho lavorato tutta l'estate, *Abbiamo voluto passare le vacanze in Italia però siamo rimasti a Belgrado уместо Volevamo passare le vacanze in Italia però siamo rimasti a Belgrado, *non potevamo conoscere Luisa perchè è partita in fretta уместо non abbiamo potuto conoscere Luisa perchè è partita in fretta, *non l'ho vista da circa due anni уместо non la vedevo da circa due anni, *non ho comprato niente perchè ho già speso tutti $i$ soldi уместо non ho comprato niente perchè avevo già speso tutti $i$ soldi, *finalmente mi è arrivato il libro che ho ordinato уместо finalmente mi ̀̀ arrivato il libro che avevo ordinato, *erano stanchi perchè hanno camminato per tre ore уместо erano stanchi perchè avevano camminato per tre ore, $*$ Quando sono arrivato in piazza, ho visto Silvia che è arrivata 15 minuti prima уместо Quando sono arrivato in piazza, ho visto Silvia che era arrivata 15 minuti prima.

Графикон бр. 3: Морфосинтаксичке грешке после завршеног нивоа А2

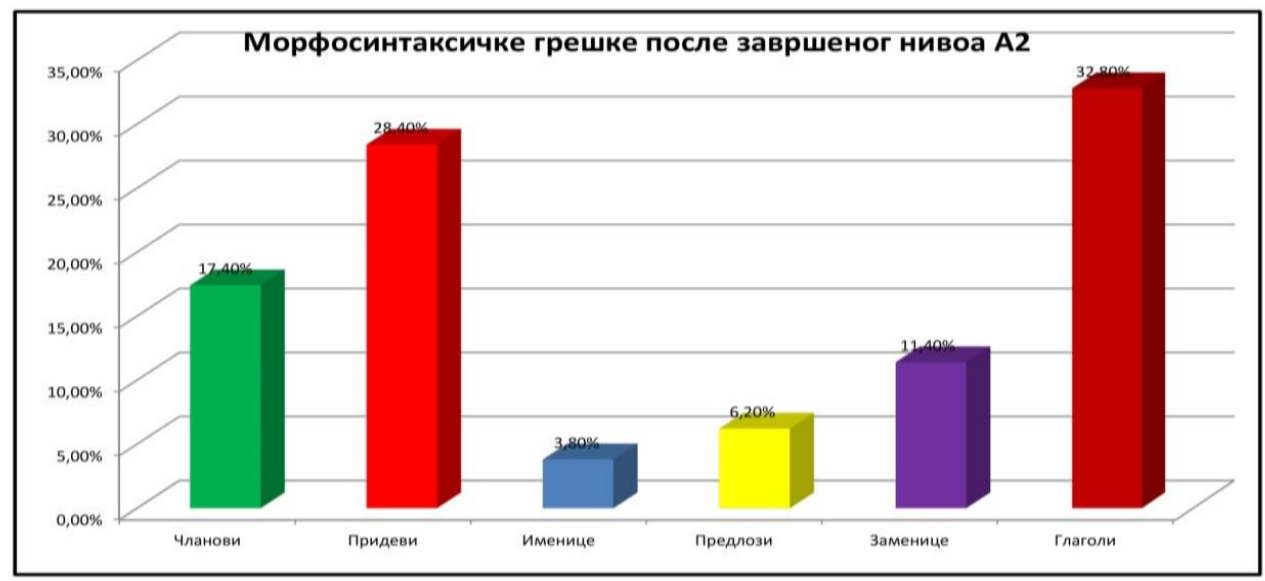


Графикон бр. 4: Морфосинтаксичке грешке после завршеног нивоа Б2

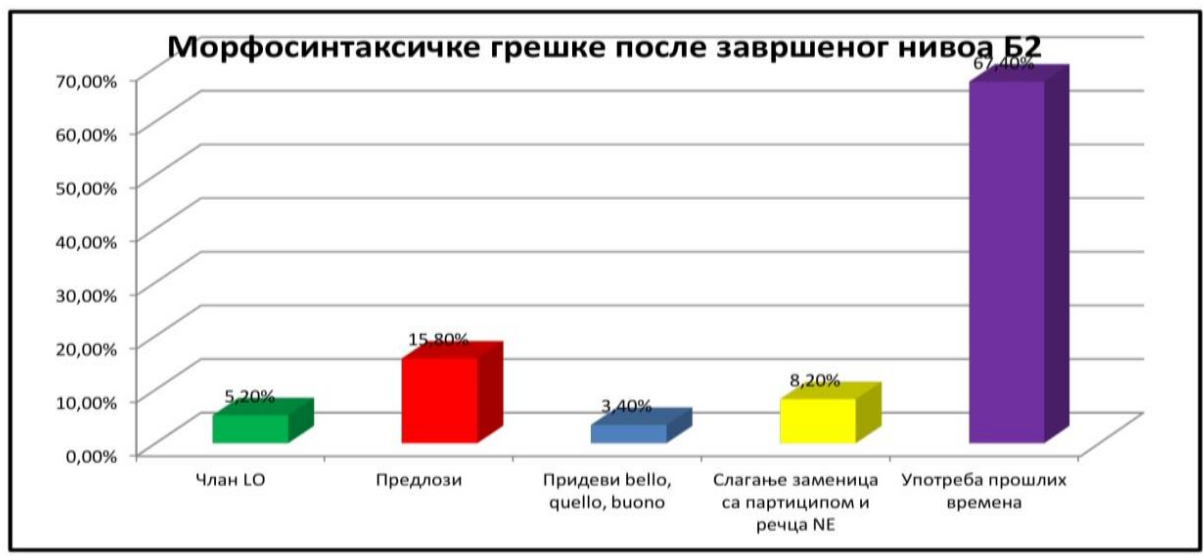

\section{4. ЗАКЉУЧАК}

Наш корпус чинило је укупно 1.104 рада (диктата, есеја и завршних испита) који су анализирани после завршеног нивоа А2, а затим и после завршеног нивоа Б2. Анализиране су правописне, лексичке и морфосинтаксичке грешке. Резултати су показали да су, у поређењу са грешкама направљеним на нивоу А2, ученици или у потпуности искоренили грешке или их у знатној мери редуковали. Ипак, неке грешке остале су фосилизоване у међујезику ученика и после две године редовне наставе и вежбања проблематичних граматичких партија. Очекивано је било да ће дате грешке на нивоу Б2 нестати. Те укорењене грешке тичу се правописа (doppie) и морфосинтаксе (члан LO, предлози, придеви bello и quello, заменица $N E$ и слагања заменица са партиципом и употребе прошлих времена). Лексичке грешке нису се фосилизовале.

Можемо да закључимо да највећу препреку србофоним ученицима представљају оне категорије речи или употреба правила која не постоје у њиховом матерњем језику (удвојени сугласници, члан, заменица $N E$, изражавање аспектуалности путем прошлих времена). Највећи проценат грешака тиче се употребе прошлих времена. Верујемо да разлог за то треба тражити у негативном трансферу из матерњег језика ученика. Наиме, у српском језику систем прошлих времена сведен је на употребу перфекта, док коришћење имперфекта и плусквамперфекта делује архаично, и они се замењују перфектом када год је то могуће (Šipčić 2013: 15). Ова чињеница могла би да објасни зашто ученици избегавају да у италијанском језику користе Imperfetto и Trapassato Prossimo у случајевима када је њихова 
употреба не опциона него неопходна. У свим случајевима грешака очигледан је снажан трансфер из матерњег језика у циљни језик. Поред интерлингвалних грешака, у раду смо издвојили и најчешће интралингвалне грешке, настале услед несавладавања или погрешне употребе правила циљног језика (погрешан облик члана, употреба предлога, избор помоћног глагола приликом грађења сложеног времена).

Мишљења смо да би најупечатљивије грешке које смо истакли у раду могле указати на области највећих потешкоћа на које наилазе србофони ученици који уче италијански језик, као и да оне могу да послуже као смернице у изради посебно осмишљеног дидактичког материјала који би водио рачуна о језичким потребама оваквих ученика.

Графикон бр. 5: Грешке после завршеног нивоа А2

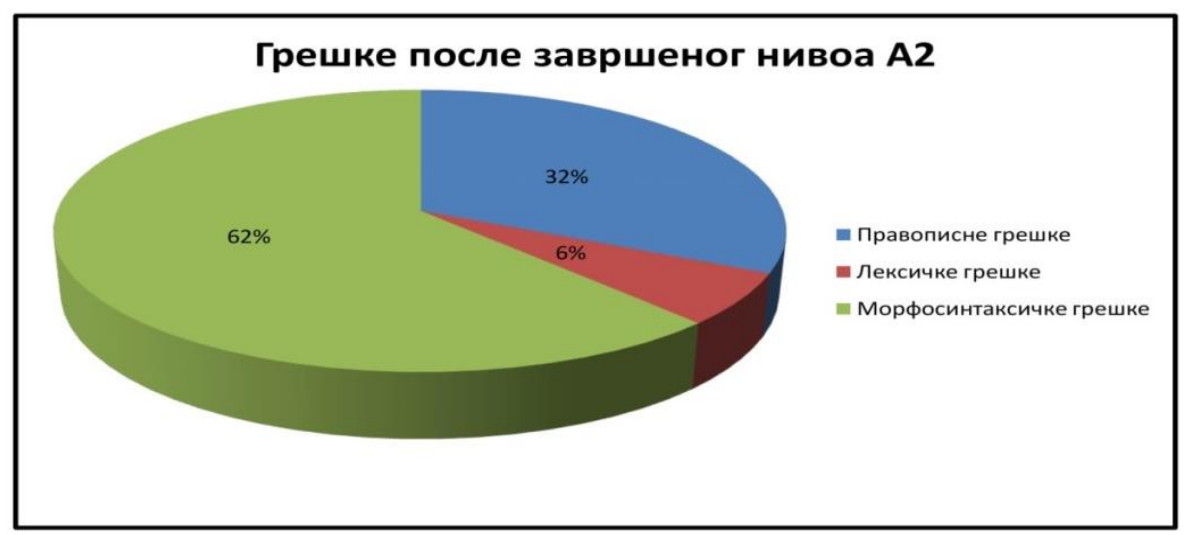

Графикон бр. 6: Грешке после завршеног нивоа Б2

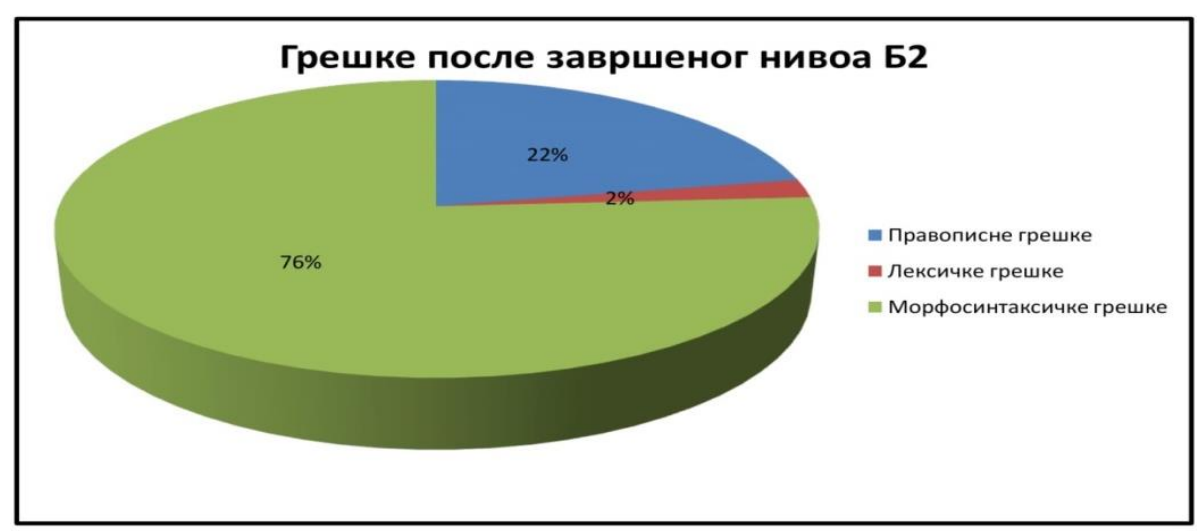


Графикони јасно указују на области највећих потешкоћа србофоних ученика који уче италијански језик. После нивоа А2 и Б2 показало се да лексичке грешке чине најмањи проценат од укупног броја грешака. Такве грешке нису ометале комуникацију, односно преношење поруке. Изненађујуће висок јесте проценат правописних грешака на оба нивоа. Сматрамо да би се број оваквих грешака могао свести на минимум уколико би се на овај сегмент обратила посебна пажња израдом диктата и писањем есеја. Очекивано висок проценат резервисан је за морфосинтаксичке грешке. Уколико би наставници језика обратили посебну пажњу и посветили више времена увежбавању оних структура које су се у нашем истраживању показале као најкритичније, верујемо да би се грешке могле спречити, или да би бар њихов број знатно био редукован.

\section{ЛИТЕРАТУРА}

Adjemian, C. (1976). "On the nature of interlanguage systems". Language Learning 26: 297-320.

Brown, H. D. (1980). "The optimal distance model of second language acquisition”. TESOL Quarterly 14: 157-164.

Brown, H. D. (2000). Principles of Language Learning and Teaching. Englewood Cliffs NJ: Prentice-Hall.

Ceković, N. (2007). Difficoltà di apprendimento dell'italiano L2 da parte dello studente serbo. Master rad. Univerzitet u Udinama.

Corder, S. P. (1967). "The significance of learner' errors". IRAL 5: 161-171.

Corder, S. P. (1971). "Idiosyncratic dialects and error analysis". IRAL: International Review of Applied Linguistics in Language Teaching 9: 147160.

Dardano, M. \& Trifone, P. (1995). Grammatica italiana con nozioni di linguistica. Milano: Zanichelli Editore.

Ellis, R. (1982). “The origins of interlanguage”. Applied Linguistics 3: 207-223.

Ellis, R. (1985). Understanding second language acquisition. Oxford: OUP.

Ellis, R. (1992). Second language acquisition and language pedagogy. Clavedon. Philadelphia. Adelaide: Multilingual Matters.

Fernández, S. (1997). Interlengua y análisis de errores en el aprendizaje del español como lengua extranjera. Madrid: Edelsa.

Gardner, R. C. (1985). Social psychology and second language learning: The role of attitudes and motivation. London: Edward Arnold. 
Han, Z. H. (2004). Fossilization in adult second language acquisition. Clevedon: Multilingual Matters.

Janićijević, N. (2016). Iskazivanje budućnosti glagolskim oblicima $i$ konstrukcijama u italijanskom $i$ srpskom jeziku. Doktorska disertacija. Univerzitet u Beogradu, Filološki fakultet.

Lenneberg, E. H. (1967). Biological Foundations of Language. New York: Wiley.

Lightbown, P. M. \& Spada, N. (1999). How languages are learned. Oxford: Oxford University Press.

Mitchell, R. \& Myles, F. (1998). Second language learning theories. London: Arnold.

Moderc, S. (2005). "Due sistemi a confronto: il perfekat serbocroato e i suoi equivalenti italiani”. Italica Belgradensia 5: 1-31.

Nemser, W. (1971). "Approximative Systems of Foreign Language Learners". IRAL 9: 115-123.

Radojević, D. (2014). Kontrastivna analiza funkcija predloških konstrukcija u italijanskom i padeža u srpskom jeziku. Doktorska disertacija. Univerzitet u Beogradu, Filološki fakultet.

Sánchez Iglesias, J. (2003). "Errores, corrección y fosilización en la didática de lenguas afines: Análisis de errores en la expresión escrita de estudiantes italianos de E/LE'. Pristupljeno: 11. 3. 2018.

URL: <http://gredos.usal.es/jspui/bitstream/10366/116103/1/84-7800-6508.pdf>.

Saville-Troike, M. (2006). Introducing second language acquisition. Cambridge: Cambridge University Press.

Selinker, L. (1972). "Interlanguage". International Review of Applied Linguistics 10: 209-231.

Selinker, L. (1992). Rediscovering interlanguage. New York: Longman.

Skehan, P. (1998). A cognitive approach to language learning. Oxford: Oxford University Press.

Šipčić, D. (2013). Upotreba glagolskih vremena u originalu i prevodu romana Il Cimitero di Praga Umberta Eka. Master rad. Univerzitet u Beogradu, Filološki fakultet.

Tarone, E. (1979). "Interlanguage as chameleon“. Language Learning 29: 181191.

Tarone, E. (1994). "Interlanguage", in The encyclopedia of language and linguistics, ed. R. E. Asher 4, (Oxford: Pergamon): 1715-1719.

Terić, G. (1996). In italiano. Priručnik kontrastivne gramatike za govornike srpskog jezika. Perugia: Edizioni Guerra. 
Vigil, N. A. \& J. W. Oller. (1976). "Rule fossilization: a tentative model". Language Learning 26(2): 281-295.

\author{
Marija N. Vujović \\ Logos, Foreign language school Belgrade \\ FOSSILIZED ERRORS IN THE WRITTEN PRODUCTION OF ITALIAN LANGUAGE \\ STUDENTS (B2 LEVEL)
}

\title{
Summary
}

Fossilization, a phenomenon that inevitably occurs in the interlanguage of students learning the target language, has been the subject of studies in the field of second language acquisition for a long time. Therefore, the purpose of this paper is to present the results of empirical research in an attempt to identify the most common fossilized errors of students at the B2 level in the Italian language using the method of Error Analysis of the corpus consisting of essays, dictatiotion and final exams of language students.in order to reduce the number of errors during the learning process and to improve language teaching. The participants were 24 students in a private language school in Belgrade whose written production was analyzed after the completion of the A2 level and then after the completion of the B2 level, and their errors were compared.

The results showed the most common student errors at the A2 level. The most frequent orthographic errors are: doppie, omission of letter $H$, lack of usage of apostrophes and accents. Errors at the level of morphosyntax concern the use of articles, prepositions (this category of words creates most problems at all levels), nouns (gender of nouns, gender of nouns ending in $-\mathrm{E}$, nouns with irregular plural), pronouns (demonstrative pronouns, $N E$, concord of pronouns with the participle, use of dative instead of object pronouns) and verbs (use of Futuro Anteriore, selecting an auxiliary verb for Passato Prossimo, use of Passato Prossimo, Imperfetto and Trapassato Prossimo).

The results also showed that, in spite of two years of training, exposure to the target language, corrections, additional exercises and explanations certain errors still persist in the learners' interlanguage although it was believed that they would disappear at this level. These fossilized errors at the B2 level concern orthography (doppie) and morphosyntax (article $L O$, prepositions, adjectives bello and quello, pronoun $N E$, concord of pronouns with participle and use of past tenses). Lexical errors are not the type of errors that became fossilized.

Key words: fossilization, errors, error analysis, interlanguage, Italian language, Serbophone speakers, A2 level, B2 level.

Примљено: 11. 2. 2019. Прихваћено: 19. 8. 2019. 